\title{
The Effect of Pre-Task Planning Time on L2 Learners' Narrative Writing Performance
}

\author{
Keivan Seyyedi ${ }^{1}$, Shaik Abdul Malik Mohamed Ismail ${ }^{1}$, Maryam Orang $^{2} \&$ Maryam Sharafi Nejad ${ }^{1}$ \\ ${ }^{1}$ School of Educational Studies, Universiti Sains Malaysia, Penang, Malaysia \\ ${ }^{2}$ School of Languages, Literacies and Translation, Universiti Sains Malaysia, Penang, Malaysia \\ Correspondence: Keivan Seyyedi, School of Educational Studies, Universiti Sains Malaysia, 11800, Penang, \\ Malaysia. Tel: 601-4249-5710. E-mail: kevansayyedi@yahoo.com
}

\author{
Received: September 5, 2013 Accepted: September 22, 2013 Online Published: November 5, 2013 \\ doi:10.5539/elt.v6n12p1 URL: http://dx.doi.org/10.5539/elt.v6n12p1
}

\begin{abstract}
Building on Baddeley's cognitive psychology (2007) and Skehan's Limited Attentional Capacity Model (2009), this article reports a study of the effects of pre-task planning time (strategic planning time) on Malaysian English learners' written narratives elicited by means of a picture composition. 50 first-year undergraduate students studying at Universiti Sains Malaysia (USM) Penang were served as the participants of this study. All the participants achieved band four from Malaysian University English Test (MUET). They were randomly selected and divided into two equal groups of with pre-task planning time and without pre-task planning time. Each group was asked to narrate a story under the two different conditions. Participants in pre-task planning time group was required to plan for their performance for 10 minutes and take notes before they performed the tasks, whilst the participants in without pre-task planning time group began writing immediately. The learners' writing performance was measured for complexity, accuracy, and fluency (CAF). Independent samples t-test was employed to analyze the collected data. Results indicated that pre-task planning time had no effect on the accuracy of the learners' writing performances, but led to more fluency and complexity.
\end{abstract}

Keywords: pre-task planning time, strategic planning time, complexity, accuracy, fluency

\section{Introduction}

For decades, the teaching and learning of language has been an area of interest to many researchers, syllabus designers, teachers, and evaluators. As a result, a number of approaches, based on different theories, have emerged in the field (Schmidt, 2001). Traditional approaches to language teaching were characterized by their emphasis on form at the expense of meaning. Teachers adopting such approaches tended to teach specific linguistic forms, and designed uncontextualized drills and exercises to practice these forms. Consequently, learners became comparatively competent in grammar and reading if given enough time, but lacked the ability to communicate in real situations. At this time the assumption seemed to be that focusing only on linguistic forms in language teaching was not enough but this needed to be accompanied by a desire to extend ability to convey meaning (Skehan, 2003).

In the 1970s, there were considerable moves towards the communicative language teaching (CLT) approach (Brumfit \& Johnson, 1979). The aim of CLT was similar to previous methods such as oral-situational or the audio-lingual methods which also increased the capacity to utilise language communicatively. Nevertheless, there was a difference in the ways through which the objective was attained. Previous methods considered language to be a system composed of a set of linguistic forms whereas CLT was based on communicative competence theory (Ellis, 2003) with 'communicative activity' as its unit of analysis (Skehan, 2003). Language was not just a system for manipulating its structure, but it was considered a medium through which to communicate actively. Instruction was organised around objectives, themes, functions, and notions.

In the 1980s, the term 'communicative activity' was replaced by 'task' (Rubdy, 1998). Not only were tasks used in CLT but some methodologists tried to incorporate particular kinds of tasks into classical or traditional approaches of language teaching. This method of instruction is called task-supported language teaching (TSLT) (Ellis, 2003), and is considered to be the weak version of task based instruction (Skehan, 2003). The strong version is referred to task-based language teaching (TBLT). In the case of TSLT, tasks serve only as the means 
for implementing a methodological procedure, whereas in TBLT tasks serve as units of teaching, and whole courses are designed around those tasks (Ellis, 2003).

Since meaning (fluency) is considered more important than form (complexity and accuracy) in TBLT, teaching grammar explicitly is downplayed (Shehadeh, 2005). As a result, there came a realization that TBLT does not expand a learners' linguistic competence efficiently (Ellis \& Yuan, 2004). Thus, there was a challenge between those who focussed on form and on meaning. On the one hand, traditional approaches failed to develop a learner's fluency and use of language in real communications, but on the other hand, TBLT "does not satisfy the students' expectations regarding the need for accurate language use" (Yuan, 2001, p. 3).

Despite this, many researchers and teachers have been interested in TBLT (e.g. Bygate, 1999, 2001; Ellis, 2005; Foster \& Skehan, 1999; Gilabert, 2005, 2007; Robinson, 2007b, 2007c, 2011; Skehan, 1998, 2003, 2009; Skehan \& Foster, 2001). Tavakoli and Foster (2011) outlined three overlapping reasons why task-based research has been so widespread in the empirical research area for more than two decades: First, research attempts to clarify the proposition that undertaking a task can cause interlanguage (IL) change by having learners engage with and retain information about the L2 when using it (Swain, 1995). Secondly, if research discovers the task characteristics that influence a learner's language processing, it helps to provide sound principles for syllabus design empirically rather than through more intuition-based reasoning (Bygate, 1999). Finally, research sheds light into the argument that task design, and the conditions of performing a task, can be selected deliberately by teachers to help learners focus their attention on the language aspects being learned (Samuda, 2001; Skehan, 1998).

As a researcher, the growing interest in TBLT motivated me to conduct research in order to determine the role of "task" in L2 writing performance. As I went on with my studies, I realized that according to Skehan (2003) tasks can be performed under different conditions (e.g., +/- pre-task planning time; +/- within task planning time (Ellis, 2005)). Although there has been progress in the influence of different task characteristics and task conditions on oral performance (Samuda \& Bygate, 2008), fewer studies have been undertaken into how these characteristics and conditions influence the written performance of L2 learners (Kuiken \& Vedder, 2008; Ong \& Zhang, 2010).

Consequently, this study attempts to fill this gap and investigates the way the English narrative writing performance of L2 learners will be affected by $+/$ - pre-task planning time as a task condition. This can help both English language teachers and examiners to choose tasks that have the potential to achieve specifically targeted features of writing competence.

\section{Related Studies}

One of the earliest studies to explore the effects of strategic planning on language production was conducted by Crookes (1989). The participants were twenty Japanese English as a foreign language (EFL) learner who was asked to carry out two monologic tasks under two different planning conditions. The first planning condition was defined as "minimal pre-task planning" in which no strategic planning time was provided, while the second was defined as "ten-minute pre-task planning" in which participants were given ten minutes for strategic planning. Under the second condition, participants were asked to take notes to ensure that they were involved in planning. Crookes (1989) hypothesized that the second planning condition would be more accurate and complex and would produce forms at a higher developmental level. He believed that planners created a language that was more complex and fluent, but less accurate than non-planners. He suggested that planners use planning time to complexify the task, which resulted in a greater amount of subordination with no greater accuracy and challenging language used.

Sangarun (2005) also sought the effects of focusing on form and meaning in strategic planning. The participants were 40 Grade 11 Thai EFL intermediate students. Four strategic task planning conditions and two task types were used in the study. Three of the four strategic task conditions were established based on their particular focus (i.e., language-focused, content-focused, and content and language-focused) while the fourth strategic task planning condition was minimal strategic planning, which was a control condition. The two task types had, respectively, a low and a high level of cognitive and linguistic demands. She found that complexity was greater only in content-focused and content and language-focused strategic task planning, while accuracy and fluency were greater in all three conditions (i.e., content-focused, language-focused and content and language-focused). As to task demand, tasks with high cognitive and linguistic demands promoted complexity while tasks with low cognitive and linguistic demands promoted accuracy and fluency.

Kawauchi (2005) examined the effects of strategic planning on oral narrative tasks and attempted to discover whether proficiency levels play a role in the effect and type of planning. 39 Japanese English learners with different proficiency levels (16 low-intermediate; 12 high-intermediate; and 11 advanced) participated in the 
study. Two planning conditions were used (no planning and strategic planning). All participants performed both the unplanned and planned tasks. In the first stage, under the unplanned conditions, participants were asked to describe the set of pictures assigned to them without preparation, and two minutes were provided to describe the story. In the second stage, they were told they would do the same task again, but before that, and after being divided into three groups, each group was asked to do one of the three strategic planning activities that were used in the study - Writing, Rehearsal and Reading. For the Writing performance, they were asked to write out what they intended to say when they carried out the unplanned task. For Rehearsal, they were asked to rehearse by saying aloud what they meant to say in the unplanned task. For Reading, they were provided with a model passage of the picture story and were told to read it silently. Each group performed each activity within ten minutes of time.

Kawauchi (2005) discovered that strategic planning had positive consequences on the CAF of oral narratives. Although greater complexity was found in the planned performance of all groups, it seemed less helpful to the advanced EFL group. Moreover, task planning had greater effects on the fluency of the high-intermediate EFL group than the low intermediate and advanced EFL group. The low intermediate EFL group benefited significantly from the opportunity to plan, in terms of accuracy. In conclusion, planning improved the fluency and complexity of the high-intermediate EFL group, and the accuracy of the low-intermediate EFL group. The advanced EFL group benefited from the planning opportunity much less than the two other groups. The performance of the three groups in the unplanned task corresponded to their level of proficiency.

Finally, in a similar study to Kawauchi (2005), Rahimpour and Jahan (2011) investigated the effect of planning time and proficiency level on the written performance of EFL learners, for concept load, accuracy, complexity, and fluency. Planning time was implemented at two levels of pre-task planning time and on- line planning time. 144 Iranian EFL learners comprised two groups of pre-task planning time in high and low proficiency levels, and two groups of on-line planning time in high and low proficiency levels. The statistical analysis indicated that low-proficiency learners were advantaged more from pre-task planning time regarding concept load, complexity, and fluency. Learners at a high proficiency level appeared to benefit from pre-task planning time concerning concept load and accuracy, however.

\section{Context of the Study}

In Malaysian education students spend 11-13 years learning English (6 years in primary school and 5-7 years in secondary school), but a large number of students have been unable to master English writing skills upon completing secondary school (Hiew, 2012). Malaysian students consider writing English to be one of their greatest weaknesses (Michael, 2003). Chitravelu, Sithamparam, and Teh (2005) have described how most Malaysian students are less proficient in their writing skills and do not know how to carry out their written assignments satisfactorily. Learners feel that writing is a minor skill. Rao (2007) points out that learners find English writing to be a difficult task because writing skills demand many cognitive and linguistic strategies about which these learners are uncertain.

In the Malaysian education programme, the English papers in the national examinations such as Ujian Penilaian Sekolah Rendah (UPSR) (Note 1), Penilaian Menengah Rendah (PMR) (Note 2), Sijil Pelajaran Malaysia (SPM) (Note 3) or Sijil Tinggi Persekolahan Malaysia (STPM) (Note 4) focus on the writing skills of the students; including sections requiring them to write either guided or unguided essays. The results of these examinations indicate whether the students have completely accomplished the essential language aspects of writing skills, their lack is clearly seen among the low proficiency learners (Malaysian Ministry of Education (MOE), 1998). According to the studies and analysis of national examinations conducted by the Examination Division of MOE, most low and intermediate proficiency level students seem to have difficulty with writing English. Some Malaysian students write in simple sentence structures which do not reflect their level of thinking as a university student (Rahim, Abdullah, \& Ishak, 2008). In some cases students write very short and incomprehensible narrative, employ the national language (Bahasa Malaysia) or even just copy from those who do have the ability of writing longer narrative. At the tertiary level some students have problems in generating ideas for writing (Rahim et al., 2008).

Furthermore, due to the high importance placed on national examinations in Malaysia, a number of teachers focus on the instruction of grammar and ignore the communicative aspects of learning language (Musa, Lie, \& Azman, 2012). Although grammar is "a necessary component of any language teaching program" (Rutherford, 1987, p. 9), and plays a key role in language teaching, focusing on grammar or form (accuracy and complexity) can draw learner attention away from meaning (fluency), and eventually communicative competence will be diminished. On the other hand where English language teaching is based on the communicative approach in 
Malaysia (MOE, 2003) meaning is emphasized and form is neglected, which causes students to have difficulty using the correct English grammar in their writing (Maros, Tan, \& Salehuddin, 2007). Consequently, these two extremes towards meaning and form discourage students from having a good command of English writing, which contains all three performance areas of complexity, accuracy, and fluency (CAF) simultaneously.

Studies have shown that, it is unusual to use all three aspects of language simultaneously while performing a task (Foster \& Skehan, 1999; Skehan, 2009; Yuan \& Ellis, 2003). Cognitively speaking, the central issue is that learners are unable to give their attention to all aspects of language equally at the same time. The rationale behind this dilemma is that human attentional resources and working memory are limited (Baddeley, 2007; Skehan, 2009) and a choice to allocate attention to one area of CAF may be at the expense of other areas (Foster \& Skehan, 1999, p. 216); that is, when one area progresses another suffers since limited attention is accessible and this might cause lower performance in the other areas. These trade-off impacts have been seen between accuracy and fluency, and between accuracy and complexity (Foster \& Skehan, 1996; Mehnert, 1998; Yuan \& Ellis, 2003).

A number of theories have been suggested to account for these problems. One was the question of emphasising pre-task planning time, which skilled writers normally employ. In many cases teachers do not provide students with pre-task planning time and in other cases the students are not given the proper amount of time to plan for their writing before carrying out written tasks. Consequently, learner writing performance may be weak and unsuccessful. It is hypothesized that providing learners with a chance to plan for their production before performing the main tasks decreases the cognitive burden during the processing of language production and allows them to focus on various aspects of language to recover information in working memory, in order to achieve a more successful task performance (Ellis, 2005). Skehan (1996) also suggests that pre-task planning time may encourage L2 learners to focus on form and thus resolve the competition for attentional resources between meaning and form while performing a task.

Consequently, based on the importance of pre-task planning time in English writing, and since English writing research has not received much attention in Malaysian context, there is a need to study the effects of $+/$ - pre-task planning time on L2 learners' narrative writing performance.

Based on the issues related to planning time and in order to investigate whether this characteristic as the independent variables has a considerable effect on L2 learners' narrative writing performance as the dependent variable, the researcher tried to answer the following question:

What is the effect of $+/$ - pre-task planning time on CAF of L2 learners' narrative writing production?

Also, in the light of the above-mentioned purpose and based on the stated research question the following hypotheses were proposed:

1) Pre-task planning time will have a significant effect on complexity of L2 learners' narrative writing performance in terms of lexical density.

2) Pre-task planning time will have a significant effect on accuracy of L2 learners' narrative writing performance in terms of error-free clauses.

3) Pre-task planning time will have a significant effect on fluency of L2 learners' narrative writing performance in terms of number of words per minute.

\section{Method}

\subsection{Participants}

Fifty first-year undergraduate students, studying at Universiti Sains Malaysia (USM) in Penang, served as the participants of this study. Cluster sampling was used to select participants from a population of 300 students. For this purpose three classes were chosen randomly and combined together. Then the students were divided into two equal groups of 25. To ensure homogeneity of the groups studied in terms of general proficiency, the researcher selected those participants who achieved band four from Malaysian University English Test (MUET). The participants had different first language (L1) backgrounds, including Malay, Chinese, and Indian meanwhile all had taken classes in which activities were common and they are not allowed to use their L1. They also contacted with English inside and outside the classroom. At the time of this study, the participants were studying Academic English course.

\subsection{Research Instrument}

Among different types of pedagogic tasks, narrative tasks are the most frequent ones employed in the literature (Foster \& Skehan, 1996; Skehan \& Foster, 1999; Tavakoli \& Skehan, 2005; Tavakoli \& Foster, 2011). Narrative 
tasks as stated by Tavakoli and Skehan (2005) refer to those stories based on a sequenced set of picture prompts which are given to participants to elicit language performance. The task used in the present study is a story-narration based on a series of six frame cartoons adapted from Tavakoli and Foster (2011), in which these tasks were administered orally (see Appendix).

\subsection{Measures of Language Production}

In this study, CAF measures were developed to evaluate the quality of the participants' written performance.

\subsubsection{Complexity}

Complexity index of this study was lexical density. Following Rahimpour and Jahan (2011) lexical density was coded through the ratio of lexical or 'open class', words (full verbs, nouns, adjectives and adverbs ending in -ly) to total words and multiplied by 100 .

\subsubsection{Accuracy}

To code accuracy for the participants' written performance of the present study, following Ellis and Yuan (2004), error-free clauses - the percentage of clauses that do not contain any errors was utilized. All syntactical, morphological, and lexical choice errors were considered.

\subsubsection{Fluency}

In this study fluency was achieved by calculating number of words per minute (production rate): the number of words produced divided by the total number of minutes each participant used for completing a task (Skehan and Foster, 1999).

\section{Statistical Analysis}

To answer the raised question of the study and find out the way the independent variables of pre-task planning time affect the dependent variables, the raw scores of the participants were fed into the computer software SPSS (version 20) for further data analysis. Then, the independent samples t-test was adopted to find out the effect of planning condition.

\section{Results}

\subsection{Complexity Measure}

Table 1 provides the means, standard deviations, and standard errors of means for the complexity of planned vs. unplanned conditions. As shown, there is a great difference between the two means. Learners who were given the opportunity to plan while performing the task outperformed those who were not given the opportunity to plan prior to writing in terms of lexical complexity.

Table 1. Group statistics for comparing complexity in planned vs. unplanned conditions

\begin{tabular}{llllll}
\hline Measure & Planning & $\mathrm{N}$ & Mean & SD & SEM \\
\hline Complexity & Planned & 25 & 46.4612 & 3.09868 & .61974 \\
& Unplanned & 25 & 44.4352 & 2.81770 & .56354 \\
\hline
\end{tabular}

In Table 2, the significance of the independent samples test is 0.19 which is less than 0.05 . It can therefore be concluded that the research hypothesis claiming that "pre-task planning time will have a significant effect on complexity of L2 learner narrative writing performances in in terms of lexical density" is accepted.

Table 2. Independent samples test to compare complexity in planned vs. unplanned conditions

\begin{tabular}{llllll}
\hline & \multicolumn{2}{l}{$\begin{array}{l}\text { Levene's Test for Equality } \\
\text { of Variances }\end{array}$} & t-test for Equality of Means \\
\cline { 2 - 6 } & $\mathrm{F}$ & Sig. & $\mathrm{T}$ & $\mathrm{df}$ & Sig. (2-tailed) \\
\hline Equal variances assumed & .000 & .996 & 2.419 & 48 & $.019^{*}$ \\
Equal variances not assumed & & & 2.419 & 47.573 & .019 \\
\hline
\end{tabular}




\subsection{Accuracy Measure}

Regarding accuracy, learners under planned conditions produced more error-free clauses. Table 3 displays the standard deviations, means, and standard errors of means for the accuracy of planned vs. unplanned conditions. As shown, learner means of accuracy are 0.6760 and 0.5868 for planned and unplanned conditions respectively. It means that learners in planned conditions outperformed learners in unplanned condition for accuracy.

Table 3. Group statistics for comparing accuracy in planned vs. unplanned conditions

\begin{tabular}{llllll}
\hline Measure & Planning & $\mathrm{N}$ & Mean & SD & SEM \\
\hline Accuracy & Planned & 25 & .6760 & .17909 & .03582 \\
& Unplanned & 25 & .5868 & .15497 & .03099 \\
\hline
\end{tabular}

However as Table 4 indicates, there is no statistical difference between planned and unplanned conditions $(p=0.066)$. As a result, the research hypothesis predicting that "pre-task planning time will have a significant effect on the accuracy of L2 learner narrative writing performance in terms of error-free clauses" is rejected.

Table 4. Independent samples test to compare accuracy in planned vs. unplanned conditions

\begin{tabular}{lllllll}
\hline & \multicolumn{2}{l}{$\begin{array}{l}\text { Levene's Test for Equality } \\
\text { of Variances }\end{array}$} & \multicolumn{2}{l}{ t-test for Equality of Means } \\
\cline { 2 - 7 } & $\mathrm{F}$ & Sig. & $\mathrm{T}$ & $\mathrm{df}$ & Sig. (2-tailed) \\
\hline Equal variances assumed & .751 & .391 & 1.883 & 48 & .066 \\
Equal variances not assumed & & & 1.883 & 47.029 & .066 \\
\hline
\end{tabular}

\subsection{Fluency Measure}

Table 5 delineates the standard deviations, means, and standard errors of means for the fluency of planned vs. unplanned conditions. It suggests that learners obtained higher mean scores of fluency under planned condition compared to those who performed the same task under unplanned condition.

Table 5. Group statistics for comparing fluency in planned vs. unplanned conditions

\begin{tabular}{llllll}
\hline Measure & Planning & $\mathrm{N}$ & Mean & SD & SEM \\
\hline Fluency & Planned & 25 & 10.2236 & 1.64061 & .32812 \\
& Unplanned & 25 & 8.8376 & 1.93103 & .38521 \\
\hline
\end{tabular}

Table 6 shows the significance of the independent samples test which equals 0.009 . The significance level is less than 0.05 therefore the research hypothesis arguing that "pre-task planning time will have a significant effect on fluency of L2 learner narrative writing performance in terms of number of words per minute" is accepted.

Table 6. Independent samples test to compare fluency in planned vs. unplanned conditions

\begin{tabular}{|c|c|c|c|c|c|}
\hline & \multicolumn{2}{|c|}{$\begin{array}{l}\text { Levene's Test for Equality } \\
\text { of Variances }\end{array}$} & \multicolumn{3}{|c|}{ t-test for Equality of Means } \\
\hline & $\mathrm{F}$ & Sig. & $\mathrm{T}$ & df & Sig. (2-tailed) \\
\hline Equal variances assumed & 1.058 & .309 & 2.735 & 48 & $.009^{*}$ \\
\hline Equal variances not assumed & & & 2.735 & 46.779 & .009 \\
\hline
\end{tabular}




\section{Discussion and Conclusions}

\subsection{Complexity}

When complexity is concerned, the findings indicate that planning has a positive effect on complexity of the participants' performance.

Some previous research reporting the gain in complexity as a result of planning time conditions includes Crookes, 1989; Foster and Skehan,1999; Gilabert, 2005; Mehnert, 1998; Rahimpour and Hazar, 2008; Skehan and Foster, 1997; Tavakoli and Skehan, 2005; Wigglesworth, 1997. This can be justified according to the fact that planners tend to focus on meaning and plan the content of their performance and thus, produce more complexity. However, findings of other studies reported no gain in complexity. In her study, Ortega (1999) did not find any differences in lexical range between planned and unplanned tasks, but she admitted that this may have been due to the type of measure she used for the calculation, type-token ratio, which is sensitive to text length. While her protocol analysis reports suggested that learners use planning time to access words and consider different possibilities, her results did not show any gains in lexical complexity, which made her conclude that (Ortega, 1999, p. 133): "the lack of consistently higher degrees of lexical richness in planned output seems in need of explanation".

\subsection{Accuracy}

Unlike fluency and complexity, for which past studies have generally obtained positive results of planning, the effects of planning on accuracy have been inconclusive, because some studies have shown positive effects whereas other studies have shown partial or no effect (Ellis, 2005, 2009; Kawauchi, 2005, Ortega, 1999).

Results of the present study indicated that planning had no effect on the accuracy of the performance. This finding supports the results of the other studies in the literature (Crookes, 1989; Gilabert, 2005; Ortega, 1995, 1999; Wigglesworth, 1997). Results of these studies and the present study suggest that when learners are allowed to plan, they choose to focus on meaning and plan what they want to write rather than planning grammatical forms (Sangarun, 2005).

On the contrary, there exist other studies in the literature that report opposite results indicating that planning leads to more accurate performance (Foster and Skehan, 1996; Mehnert, 1998, Rahimpour and Hazar, 2008; Skehan and Foster, 1997; Tavakoli and Skehan, 2005). According to Skehan and Foster (1997) when planning is carried out CAF enters into some degree of competition with one another and participants tend to prioritize on some aspects of language not all.

\subsection{Fluency}

The findings for this study indicate that pre-task planning has a significant and positive effect on fluency of the participants' performance. The findings of the present study present are in line with the results of the previous research in the literature (Foster and Skehan, 1996; Gilabert, 2005; Mehnert, 1998; Rahimpour and Hazar, 2008; Skehan and Foster, 1997; Tavakoli and Skehan, 2005; Wigglesworth, 1997). Findings of all of the studies mentioned indicated that providing learners with sufficient pre-task planning time reduces task demands, consequently makes learners to write more fluently. In contrast, the absence of pre-task planning time places a heavy burden on learners' processing and memory capacity during performance, by increasing the cognitive load and consequently reducing their fluency.

\section{References}

Baddeley, A. D. (2007). Working memory, thought, and action. Oxford: Oxford University Press.

Brumfit, C., \& Johnson, K. (1979). The communicative approach to language teaching. Oxford: Oxford University Press.

Bygate, M. (1999). Quality of language and purpose of task: Patterns of learners' language on two oral communication tasks. Language Teaching Research, 3(3), 185-214. http://dx.doi.org/10.1177/136216889900300302

Bygate, M. (2001). Effects of task repetition on the structure and control of language. In M. Bygate, P. Skehan, $\&$ M. Swain (Eds.), Researching pedagogic tasks: Second language learning, teaching and testing (pp. 23-48). London: Longman.

Chitravelu, N., Sithamparam, S., \& Teh, S. C. (2005). ELT methodology: Principles and practice. Shah Alam: Oxford Fajar.

Crookes, G. (1989). Planning and Interlanguage variation. Studies in Second Language Acquisition, 11(4), 
367-383. http://dx.doi.org/10.1017/S0272263100008391

Ellis, R. (2003). Task-based language learning and teaching. Oxford: Oxford University Press.

Ellis, R. (2005). Planning and task performance in a second language. Amesterdam: John Benjamins Publishing Company.

Ellis, R., \& Yuan, F. Y. (2004). The effects of planning on fluency, complexity, and accuracy in second language narrative writing. Studies in Second Language Acquisition, 26(1), 59-84. http://dx.doi.org/10.1017/S0272263104261034

Foster, P., \& Skehan, P. (1996). The influence of planning and task type on second language performance. Studies in Second Language Acquisition, 18(3), 299-323. http://dx.doi.org/10.1017/S0272263100015047

Foster, P., \& Skehan, P. (1999). The influence of source of planning and focus of planning on task-based performance. Language Teaching Research, 3(3), 215-247. http://dx.doi.org/10.1177/136216889900300303

Gilabert, R. (2005). Task complexity and L2 narrative oral performance. Unpublished Ph. D. Dissertation. The University of Barcelona, Spain.

Gilabert, R. (2007). Effects of manipulating task complexity on self-repairs during L2 oral production. International Review of Applied Linguistics in Language Teaching (IRAL), 45(3), 215-240.

Hiew, W. (2012). English language teaching and learning issues in Malaysia: Learners' perceptions via facebook dialogue journal. Journal of Arts, Science \& Commerce, 3(1), 11-19.

Kawauchi, C. (2005). The effects of strategic planning on the oral narratives of learners with low and high intermediate L2 proficiency. In R. Ellis (Ed.), Planning and task performance in a second languages (pp. 239-277). John Benjamins Publishing Company.

Kuiken, F., \& Vedder, I. (2008). Cognitive task complexity and written output in Italian and French as a foreign language. Journal of Second Language Writing, 17(1), 48-60. http://dx.doi.org/10.1016/j.jslw.2007.08.003

Malaysia, M. O. E. (1998). A glance at the Malaysian education system. Retrieved November 15, 2012, from $\mathrm{http}: / /$ www.studymalaysia.com/education/art_education.php?id=edusystem

Mehnert, U. (1998). The effects of different lengths of time for planning on second language performance. Studies in Second Language Acquisition, 20(1), 83-108.

Michael, A. J. (2003). Teaching writing: Essays and summaries for examinations. In M. E. Vethamani (Ed.), Readings in TESL Vol. 1: Essays in honour of Hyacinth Gaudart (pp. 40-52). Sabadi.

Musa, N. C., Lie, K. Y., \& Azman, H. (2012). Exploring English language learning and teaching in Malaysia. GEMA Online Journal of Language Studies, 12(1), 35-51.

Ong, J., \& Zhang, L. J. (2010). Effects of task complexity on the fluency and lexical complexity in EFL students' argumentative writing. Journal of Second Language Writing, 19(4), 218-233. http://dx.doi.org/10.1016/j.jslw.2010.10.003

Ortega, L. (1999). Planning and focus on form in L2 oral Performance. Studies in Second Language Acquisition, 21(1), 109-148.

Rahim, P. R. M. A., Abdullah, S., \& Ishak, N. R. D. A. (2008). Collaborative writing techniques as a tool in promoting writing skill to tertiary level students. Paper presented at the 6th Asia TEFL International Conference, Bali, Indonesia.

Rahimpour, M., \& Hazar, F. (2007). Interactional feedback, strategic planning and interlanguage variations. Journal of the Faculty of Letters \& Humanities (200), 48-68.

Rahimpour, M., \& Jahan, R. (2011). The effects of planning on writing narrative task performance with low and high EFL proficiency. English Language Teaching, 4(1), 120-127.

Robinson, P. (2007b). Criteria for grading and sequencing pedagogical tasks. In M. P. G. Mayo (Ed.), Investigating tasks in formal language learning (pp. 7-27). Clevedon, UK: Multilingual Matters.

Robinson, P. (2007c). Task Complexity, Theory of Mind, and Intentional Reasoning: Effects on L2 Speech Production, Interaction, Uptake and Perceptions of Task Difficulty. International Review of Applied Linguistics in Language Teaching (IRAL), 45(3), 193-213.

Robinson, P. (2011). Task-based language learning: A review of issues. Language Learning, 61, 1-36. http://dx.doi.org/10.1111/j.1467-9922.2011.00641.x 
Rubdy, R. (1998). Key concepts in ELT: Task. ELT Journal, 52(3), 264-265.

Samuda, V. (2001). Guiding relationships between form and meaning during task performance: The role of the teacher. In M. Bygate, P. Skehan, \& M. Swain (Eds.), Researching pedagogic tasks: Second language learning, teaching and testing (pp. 119-141). New York: Longman.

Sangarun, J. (2005). The effects of focusing on meaning and form in strategic planning. In R. Ellis (Ed.), Planning and task performance in a second language (pp. 111-143). Amesterdam: John Benjamins Publishing.

Schmidt, R. W. (2001). Attention. In P. Robinson (Ed.), Cognition and second language instruction (pp. 3-30). Cambridge: Cambridge University Press.

Shehadeh, A. (2005). Task-based language learning and teaching: Theories and applications. In C. Edwards, \& J. Willis (Eds.), Teachers exploring tasks in English language teaching (pp. 13-30). UK: Palgrave Macmillan.

Skehan, P. (1996). A framework for the implementation of task-based instruction. Applied Linguistics, 17(1), 38-62. http://dx.doi.org/10.1093/applin/17.1.38

Skehan, P. (1998). A cognitive approach to language learning. Oxford University Press: Oxford.

Skehan, P. (2003). Task-based instruction. Language Teaching, 36(1), 1-14. http://dx.doi.org/10.1017/S026144480200188X

Skehan, P. (2009). Modelling second language performance: Integrating complexity, accuracy, fluency, and lexis. Applied Linguistics, 30(4), 510-532. http://dx.doi.org/10.1093/applin/amp047

Skehan, P., \& Foster, P. (1997). Task type and task processing conditions as influences on foreign language performance. Language Teaching Research, 1(3), 185-211.

Skehan, P., \& Foster, P. (1999). The influence of task structure and processing conditions on narrative retellings. Language Learning, 49(1), 93-120.

Swain, M. (1995). Three functions of output in second language learning. In G. Cook, \& B. Seidlhofer (Eds.), Principle and practice in applied linguistics: Studies in honour of H. G. Widdowson (pp. 125-144). Oxford: Oxford University Press.

Tavakoli, P., \& Foster, P. (2011). Task design and second language performance: The effect of narrative type on learner output. Language Learning, 61, 37-72. http://dx.doi.org/10.1111/j.1467-9922.2011.00642.x

Tavakoli, P., \& Skehan, P. (2005). Strategic planning, task structure, and performance testing. In R. Ellis (Ed.), Planning and task performance in a second languages (pp. 239-277). Amesterdam: John Benjamins Publishing Company.

Wigglesworth, G. (1997). An investigation of planning time and proficiency level on oral test discourse. Language Testing, 14(1), 85-106. http://dx.doi.org/10.1177/026553229701400105

Yuan, F., \& Ellis, R. (2003). The effect of pre-task planning and on-line planning on fluency and complexity and accuracy in L2 monologic oral production. Applied Linguistics, 24(1), 1-27. http://dx.doi.org/10.1093/applin/24.1.1

\section{Notes}

Note 1. At the end of the six years of primary schooling, pupils are required to sit for a common public examination called the Ujian Penilaian Sekolah Rendah (UPSR)/Primary School Achievement Test (PSAT).

Note 2. At the end of the third year at the lower secondary level, students will be required to sit a public examination called the Penilaian Menengah Rendah (PMR)/Lower Secondary Assessment Test (LSAT).

Note 3. After two years of upper secondary education, students sit the public common examination Sijil Pelajaran Malaysia (SPM)/Malaysian Certificate of Education (MCOE).

Note 4. The Sixth Form (Lower and Upper Form for one and a half years) prepares students for the common public examination, namely, Sijil Tinggi Persekolahan Malaysia (STPM) which is equivalent Malaysian Higher School Certificate (MHSC). 


\section{Appendix}

Task Given to the Participants in Each Group

Narrative Task

Write a story based on the following picture series
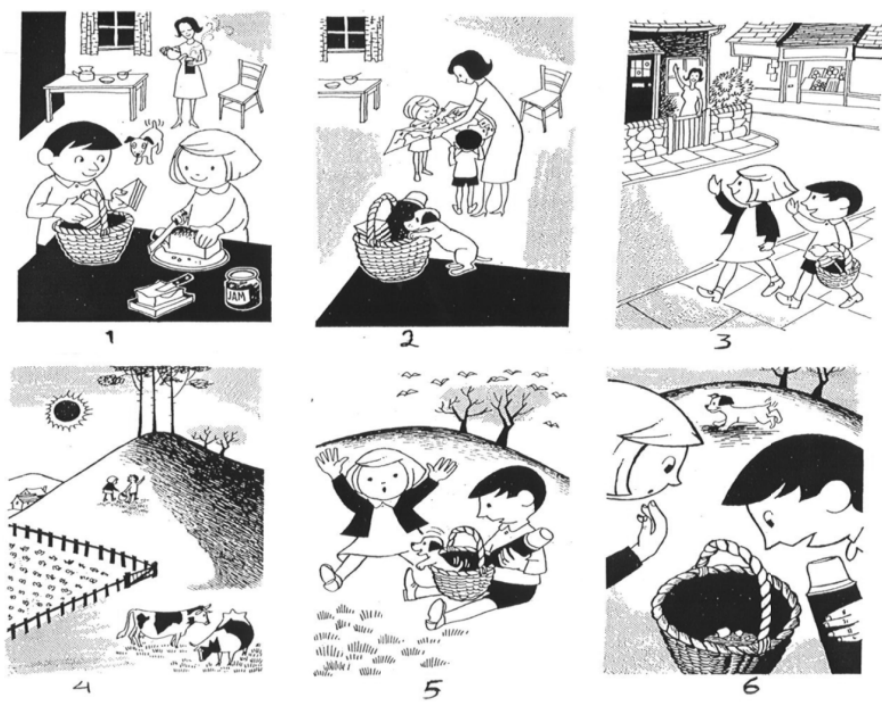

Picture 1. picnic Task, Tavakoli and Foster (2011)

\section{Copyrights}

Copyright for this article is retained by the author(s), with first publication rights granted to the journal.

This is an open-access article distributed under the terms and conditions of the Creative Commons Attribution license (http://creativecommons.org/licenses/by/3.0/). 